\title{
Amperometric Glucose Biosensor Based on Homopolymer-Chitosan Double Layered Glucose Oxidase Electrode Modified with Zinc Oxide Nanoparticles
}

\author{
Gul Ozyilmaz, ${ }^{\star}$ Ali Tuncay Ozyilmaz, Esiye Irem Bayram \\ and Ragibe Hulya Akyürekoğlu \\ University of Hatay Mustafa Kemal, Faculty of Arts \& Sciences, Department of Chemistry 31040 Hatay/ Turkey \\ *Corresponding author: E-mail: gozyilmaz@gmail.com
}

Fax: 90-326 2455867

Received: 04-05-2019

\begin{abstract}
GOD was immobilized onto polypyrrole (PPy) or poly(o-anisidine) (POA) coated Pt electrode to construct glucose sensitive biosensor. Because polymer film properties and enzyme activity affect the current response, PPy and POA synthesis conditions and also enzyme immobilization parameters were optimized in detail. The optimal monomer concentrations were determined as 25 and $50 \mathrm{mM}$ for PPy and POA, respectively, whereas scan rate was $50 \mathrm{mV} / \mathrm{s}$ for both polymer films. In case of immobilization procedure, the optimal Chitosan (Chi), glucose oxidase (GOD) and glutaraldehyde (GAL) concentrations were determined as $0.5 \%, 2 \mathrm{mg} / \mathrm{ml}$ and $0.05 \%$ for PPy and $0.5 \%, 4 \mathrm{mg} / \mathrm{ml}$ and $0.075 \%$ for POA, respectively. Zinc oxide nanoparticles (ZnONP) were co-immobilized with GOD enzyme and it was revealed that ZnONP modification enhanced the efficiencies of both electrodes in terms of current responses and stabilities. Nyquist diagrams showed that enzyme electrodes were sensitive to glucose molecule and ZnONP modification improved the sensor efficiency.
\end{abstract}

Keywords: Amperometric biosensor; polypyrrole; poly(o-anisidine); zinc oxide nanoparticles; glucose oxidase

\section{Introduction}

Glucose is one of the most analyzed components in biological fluids and foods. Compared to spectrophotometric and colorimetric methods, electrochemical methods have significant advantages in terms of simplicity, cost effective, quick way, excellent sensitivity and easy applicability. ${ }^{1-3}$ Enzyme electrodes have been widely applied to construct biosensors for analyte determination. ${ }^{4-9}$ Fabrication of the enzyme containing biosensor requires immobilization of the enzyme molecule onto/into the electrode surface. There are several strategies for immobilization techniques to obtain GOD biosensor such as crosslinking with glutaraldehyde, ${ }^{10-11}$ applying enzyme on an electrode in a gel film, ${ }^{12-17}$ entrapment or incorporation in a polymer matrix during electropolymerization, ${ }^{6,18-20}$ by covalent attachment ${ }^{21-22}$ or adsorbing onto electrode surface. ${ }^{24-26}$ Chitosan (Chi) is a type of natural cationic polymer, which has shown attractive characteristics such as film-forming ability, permeability, and good adhesion. Therefore, chitosan can be used as a gel matrix for enzyme immobiliza- tion through glutaraldehyde (GAL) or another reagent. ${ }^{27-29}$ However, the poor electrochemical conductivity of Chi reduces the performance of the enzyme-based biosensor. ${ }^{30}$ To overcome this problem, several strategies were developed by adding various materials in Chi matrix such as nanoparticles ${ }^{15,32,34}$ ionic liquid, ${ }^{29,33}$ or by modifying interface between electrode surface and Chi layer by nanoparticles, ${ }^{7,31}$ Prussian Blue ${ }^{30}$ and electropolymers. ${ }^{31}$ Electropolymerization is one of the cheap but powerful methods focusing on selective modification of various types of electrodes with desired matrices. ${ }^{3}$ Several electropolymers were used to fabricate the glucose biosensor such as $\mathrm{PPy}^{18,28,32-33}$ polyaniline (PANI), ${ }^{34-35}$ poly(o-anisidine) (POA), ${ }^{36-37}$ poly(N-methyl pyrrole) (PNMP), ${ }^{27}$ poly(o-phenylenediamine $)^{38}$ and polythophen ${ }^{39}$ derivative. Recent studies reveal that the nanostructured metal oxides with reduced size have unique advantages in immobilizing enzymes and have high sensitivity due to high surface area, desirable microenvironment, and direct electron transfer between the enzyme active sites and electrode. $\mathrm{ZnO}$ nanomaterials have been widely used for this purpose. ${ }^{40-43}$ 
The present study deals with the fabrication of a glucose biosensor based on redox polymers such as PPy and POA. Construction of biosensor was optimized in terms of PPy and POA synthesis parameters, enzyme immobilization conditions and also the amount of $\mathrm{ZnONP}$ by comparing current response in the glucose solution. Enzyme electrodes were characterized by cyclic voltammograms, Nyquist diagrams, kinetic parameters and operational stabilities.

\section{Experimental}

\section{1. Chemicals}

Aspergillus niger origin glucose oxidase (GOD) (EC 1.1.3.4), pyrrole (Py), o-anisidine (OA), Chi, $\mathrm{ZnONP}$ ( $<100$ $\mathrm{nm}$ ), glucose anhydrous, GAL were purchased from Sigma. $\mathrm{Py}$ and $\mathrm{OA}$ were used after distillation and were stored in the dark until use. All other reagents were of analytical grade and used without further purification. The polymer synthesis baths were prepared using $0.15 \mathrm{M}$ aqueous sodium oxalate solution with Py or OA monomers. Enzyme immobilization solution was obtained by mixing Chi and GOD at appropriate concentration in aqueous media. The concentration range of glucose solutions was between 0.2 and $3.0 \mathrm{mM}$ and solutions were used after $24 \mathrm{~h}$ of mutarotation equilibrium.

\section{2. Preparation of Enzyme Electrodes}

Enzyme electrodes were prepared in three steps. ${ }^{27-28}$ Firstly, homopolymer films were synthesized onto $\mathrm{Pt}$ electrode (PPy/Pt or POA/Pt). Secondly, GOD enzyme was immobilized onto polymer coated Pt electrodes by immersing in GOD containing Chi solution for 3 seconds (GOD-Chi/PPy/Pt or GOD-Chi/POA/Pt) and electrodes were dried for 2 hours open to atmosphere. Lastly, GOD$\mathrm{Chi} / \mathrm{PPy} / \mathrm{Pt}$ or GOD-Chi/POA/Pt electrodes were incubated in GAL solution for 10 seconds for crosslinking between amine groups of the enzyme and Chi to hinder GOD leakage. Modification of the GOD electrode with ZnONP was achieved by adding ZnONP to the Chi solution, and the mixture was homogenized using a sonicator. After the addition of GOD, the final solution was used to make the enzyme electrode as previously described. Electrodes were stored at $4^{\circ} \mathrm{C}$ when they were not used.

\section{3. Synthesis of Homopolymer Films}

Polymer films were achieved in a single compartment cell with three electrode configurations. The reference electrode was an $\mathrm{Ag} / \mathrm{AgCl}(3 \mathrm{M} \mathrm{KCl})$ electrode and the counter electrode was a platinum plate with a surface area of $0.25 \mathrm{~cm}^{2}$. CHI $660 \mathrm{~b}$ model electrochemical analyzer (serial number: A1420) was employed in electrochemical experiments. All potential values were referred to the $\mathrm{Ag} / \mathrm{AgCl}(3 \mathrm{M} \mathrm{KCl})$ electrode. PPy and POA films were synthesized onto Pt electrode with $0.25 \mathrm{~cm}^{2}$ surface area by cyclic voltammetry technique in a monomer solution containing $0.15 \mathrm{M}$ sodium oxalate electrolyte.

Biosensor electrodes were optimized in terms of polymer synthesis conditions (monomer concentration and scan rate) and also enzyme immobilization conditions (Chi, GOD and GAL concentration). Current values of each electrode that was constructed at different parameters were compared using glucose solution.

\section{4. Electrochemical Measurements}

Electrochemical experiments were performed in a single compartment cell with three electrode configurations. The reference electrode was an $\mathrm{Ag} / \mathrm{AgCl}(3 \mathrm{M} \mathrm{KCl})$ electrode and the counter electrode was a platinum plate with a surface area of $0.25 \mathrm{~cm}^{2}$. CHI $660 \mathrm{~b}$ model electrochemical analyzer (serial number: A1420) was employed in electrochemical experiments. The biosensor response was monitored by the chronoamperometric technique at $0.60 \mathrm{~V}$ as current value that was measured depending on hydrogen peroxide oxidation which was formed by the GOD activity in the glucose solution. The chronoamperometric measurements were performed at room temperature in steady state conditions in potassium phosphate buffer $(50 \mathrm{mM}, \mathrm{pH} 7.0)$ solution. Each measurement was lasted $120 \mathrm{~s}$.

\section{5. Characterization of Enzyme Electrodes}

The electrochemical characterization of enzyme electrodes was investigated by using cyclic voltammetry and also by AC impedance spectroscopy (EIS) techniques in the presence and in the absence of glucose. The cyclic voltammetry technique was applied at a potential range between 0.10 and $1.00 \mathrm{~V}$ by $50 \mathrm{mV} / \mathrm{s}$ scan rates. Nyquist plots were recorded at $0.60 \mathrm{~V}$ potential and in the frequency range from $10^{5}$ to $10^{-3} \mathrm{~Hz}$ using the amplitude of $4 \mathrm{mV}$ for electrochemical impedance spectroscopy investigations.

All electrodes were compared according to measured net current response depending on glucose concentration at the constant potential. The net current value, represented as $\mu \mathrm{A}$, was got by subtracting current value of the glucose-free buffer solution from those of glucose-containing solution.

$I_{\max }$ and $K_{M}$ values were calculated from Lineweaver-Burk Plot using current values depending on glucose concentrations.

Operational stabilities were investigated by 20 successive using of each electrode in $5 \mathrm{mM}$ glucose solution.

\section{Results and Discussion}

\section{1. Optimization of PPy and POA Synthesis Parameters}

In order to obtain the maximum current response, polymer film synthesizing parameters were optimized in 
terms of monomer concentration and scan rate. Because the pore size of polymer film is especially important for adsorption of GOD molecule, firstly, monomer concentrations, which were employed to obtain polymer layers on $\mathrm{Pt}$ electrode were changed between 10 and $100 \mathrm{mM}$ for PPy and 40 and $80 \mathrm{mM}$ for POA. Concentration ranges of monomers were determined according to preliminary studies. All other parameters such as scan rate, concentrations of GOD, Chi and GAL were kept constant while enzyme electrodes were constructed. Obtained electrodes were used to measure the current values depending on glucose concentrations and results were given as percentage of maximal current value in Fig. 1 and Fig. 2 for PPy and POA, respectively. As seen in Fig. 1, the highest current values and the most linear current curve were obtained for PPy electrode that was constructed using 25 $\mathrm{mM}$ pyrrole monomer.

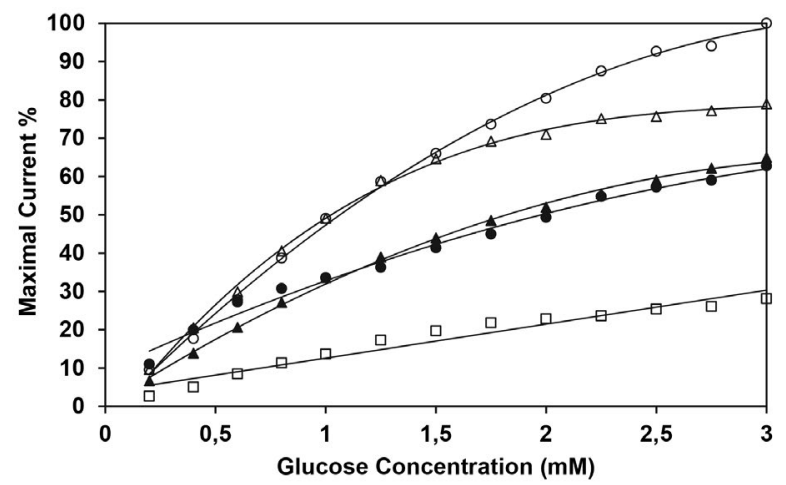

Figure 1. The effect of pyrrole concentration, that was used for PPy based electrode construction, on current values. Pyrrole concentrations: $10 \mathrm{mM}(\bullet) ; 25 \mathrm{mM}(\bigcirc) ; 50 \mathrm{mM}(\triangle) ; 75 \mathrm{mM}(\boldsymbol{\Delta})$ and $100 \mathrm{mM}(\square)$.

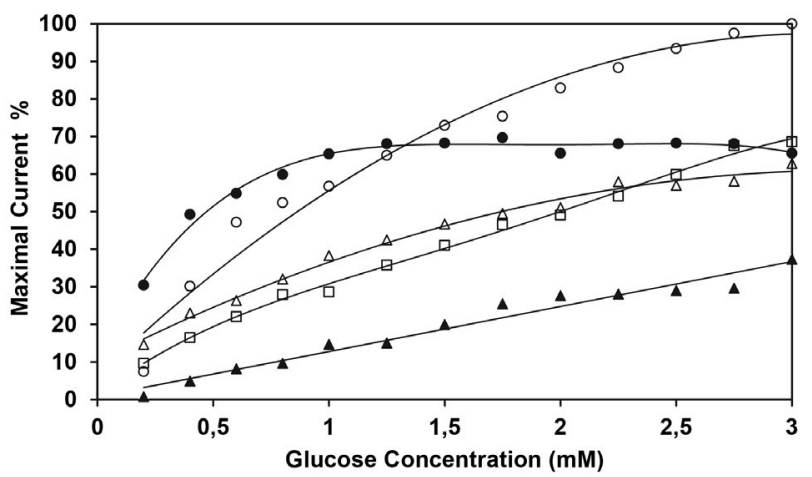

Figure 2. Current values depending on glucose concentration of GOD electrode constructed by POA layer obtaining by different o-anisidine concentrations as $40 \mathrm{mM}(\bullet) ; 50 \mathrm{mM}(\bigcirc) ; 60 \mathrm{mM}(\triangle)$; $70 \mathrm{mM}(\square)$ and $80 \mathrm{mM}(\boldsymbol{\Delta})$.

In case of POA electrode (Fig.2), the optimal o-anisidine concentration was chosen as $50 \mathrm{mM}$. The change in the current response depending on the monomer concentration used in electrode preparation of enzyme electrodes can be explained by the effect on the porosity of the polymer films. Polymerization rate is affected from several parameters such as monomer concentration, scan rate, etc. It is expected that, polymerization rate increases by increase in monomer concentration. The polymer structure generally tends to be tight stacking and to have a small pore structure as the rate of polymerization increases. Thus, the pore diameters of the polymer will be large at low monomer concentration and small at high monomer concentration. Polymer synthesis rate was low at the low monomer concentration, so pore sizes may be too high that enzyme molecule can't adsorb onto polymer film. However, polymerization rate was high at high monomer concentrations, and because the polymer film is tightly stacked, pore sizes are too small to allow the enzyme binding. The PPy and POA films formed by $25 \mathrm{mM}$ for pyrrole and 50 $\mathrm{mM}$ for o-anisidine exhibited better current response results in the different glucose concentration solution. Therefore, to construct glucose sensitive electrode, PPy and POA were synthesized in $25 \mathrm{mM}$ pyrrole and $50 \mathrm{mM}$ o-anisidine solutions, respectively in the subsequent studies. In our knowledge, the effect of monomer concentration on biosensor efficiency has not been investigated until now.

As the scan rate increases, the irregularity in the formed polymer film increases, yet, when scan rate is low, more regular and tightly stacked polymer film forms. Therefore, since the scan rate affects the structure and conductivity of the polymer, the current response of the biosensor will also be affected by the scanning rate. PPy and POA films were coated on the Pt electrode by applying scan rates of 20,50 and $100 \mathrm{mV} / \mathrm{s}$. The synthesizing of thin homopolymer films was provided with the help of proper scan number from -0.50 to $1.80 \mathrm{~V}$ for PPy and from 0.35 to $1.50 \mathrm{~V}$ for POA in $0.150 \mathrm{M} \mathrm{NaOX}$ solution with optimal monomer concentration. So, in order to maintain the same polymerization duration, 10 cycles for $20 \mathrm{mV} / \mathrm{s}, 26$ cycles for $50 \mathrm{mV} / \mathrm{s}$ and 50 cycles for 100 $\mathrm{mV} / \mathrm{s}$ were applied for the synthesis of the polymer films. Fig. 3 (PPy) and Fig. 4 (POA) represent the current re-

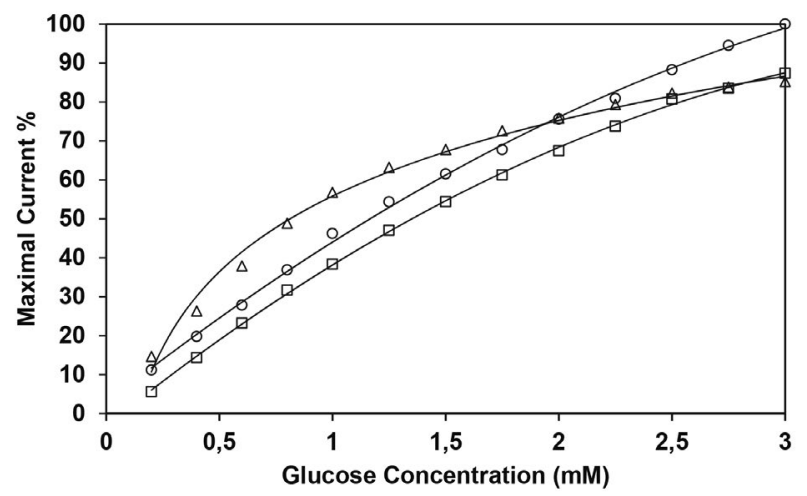

Figure 3. Current response of PPy based electrode prepared applying different scan rates; $\triangle: 20 \mathrm{mV} / \mathrm{s} ; \mathrm{O}: 50 \mathrm{mV} / \mathrm{s} ; \square: 100 \mathrm{mV} / \mathrm{s}$. 
sponse of ezyme electrodes of which polymer layers were obtained applying different scan rate. As shown in the Fig. 3, the current values of the electrode, that was obtained applying $20 \mathrm{mV} / \mathrm{s}$ scan rate, were the highest at the lower glucose concentrations. In contrast, the current values of the electrode, that was obtained applying the scan rate of $50 \mathrm{mV} / \mathrm{s}$, were high at the higher glucose concentrations. However, because of the more linear current response depending on glucose concentration was observed, $50 \mathrm{mV} / \mathrm{s}$ was selected as optimal scan rate for PPy synthesis.

In case of POA based enzyme electrode, the current values measured with the electrode prepared by applying $50 \mathrm{mV} / \mathrm{s}$ scan rate are significantly higher and the current-glucose concentration curve is highly linear. But, net current value did not observe for POA based electrode prepared by applying $20 \mathrm{mV} / \mathrm{s} \mathrm{scan}$ rate. So, $50 \mathrm{mV} / \mathrm{s} \mathrm{scan}$ rate was applied in the subsequent studies for both PPy and POA synthesis.

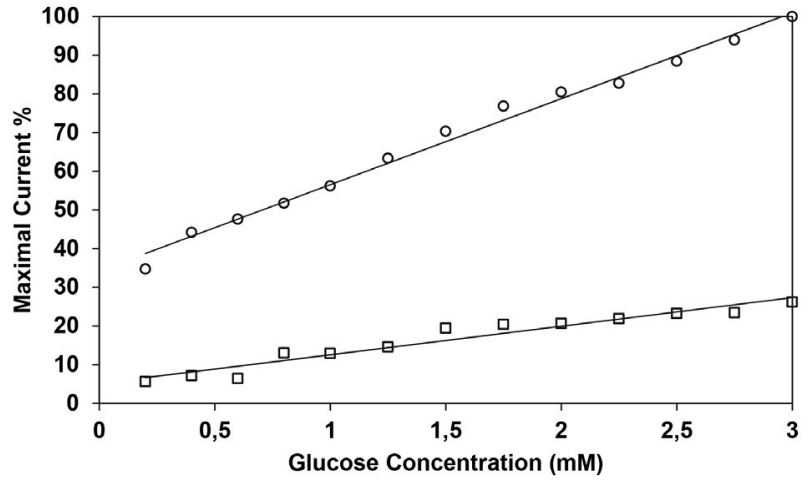

Figure 4. Current response of POA based electrode prepared applying different scan rates; O: $50 \mathrm{mV} / \mathrm{s} ; \square: 100 \mathrm{mV} / \mathrm{s}$.

The effects of enzyme immobilization conditions such as Chi, GOD and GAL concentrations were also investigated and current responses were given for $3 \mathrm{mM}$ glucose solution in the Fig. 5 A, B and C, respectively.

The highest current response for both PPy and POA based electrodes were measured by enzyme electrodes constructed using $0.5 \%$ Chi solution (Fig. 5 (A)).

As seen in the Fig. 5 (B) and (C), the maximal current responses were observed when enzyme electrodes were prepared using $0.05 \%$ GAL and $2 \mathrm{mg} / \mathrm{ml} \mathrm{GOD}$ for PPy based electrode whereas $0.075 \%$ GAL and $4 \mathrm{mg} / \mathrm{ml}$ GOD for POA based electrode. So, enzyme immobilization parameters were chosen as $0.5 \% \mathrm{Chi}, 2 \mathrm{mg} / \mathrm{ml} \mathrm{GOD}$ and $0.05 \%$ GAL for PPy whereas, as $0.5 \% \mathrm{Chi}, 4 \mathrm{mg} / \mathrm{ml}$ GOD and $0.75 \%$ GAL for POA based electrodes in the subsequent studies. Since the enzyme immobilization conditions will affect the activity of the enzyme, it is expected that it will affect the amount of hydrogen peroxide to be formed and thus the current response to be measured.
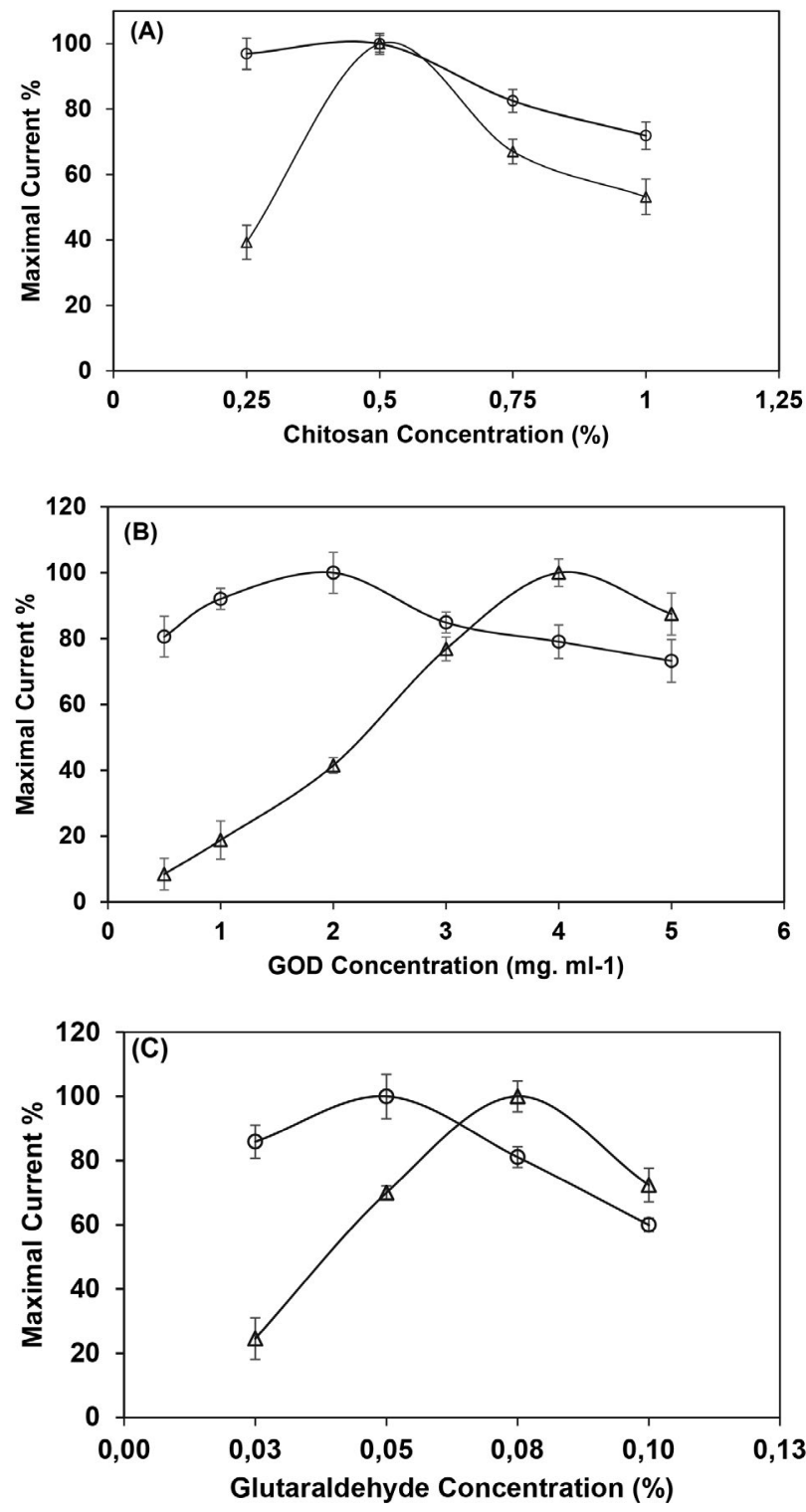

Figure 5. The effect of immobilization conditions as Chi (A), GOD (B) and $\mathrm{GAL}(\mathrm{C})$ concentrations on the current response. PPy (o); $\operatorname{POA}(\Delta)$.

\section{2. The Effect of ZnONP Modification on Current Response}

Enzyme electrodes were modified by $\mathrm{ZnO}$ nanoparticles using three concentrations as $0.1,0.5$ and $2 \mathrm{mg}$ per $\mathrm{ml}$ of Chi solution. As seen in Fig. 6 (A), it can be said that ZnONP modification enhanced the biosensor efficiency. The highest currents were obtained for PPy based electrode when $2 \mathrm{mg} \mathrm{ZnONP/ml}$ was added to GOD containing Chi solution. In case of POA based electrode, when $0.1 \mathrm{mg}$ $\mathrm{ZnONP} / \mathrm{ml}$ was used the efficiency of electrode enhanced, but for higher amounts of nanoparticle, the current values were lower than those of $\mathrm{ZnONP}$ free electrode.

Nanoparticles were used to enhance glucose oxidase electrode in the literature. ${ }^{35,43-46}$ German et al $(2015)^{43}$ 

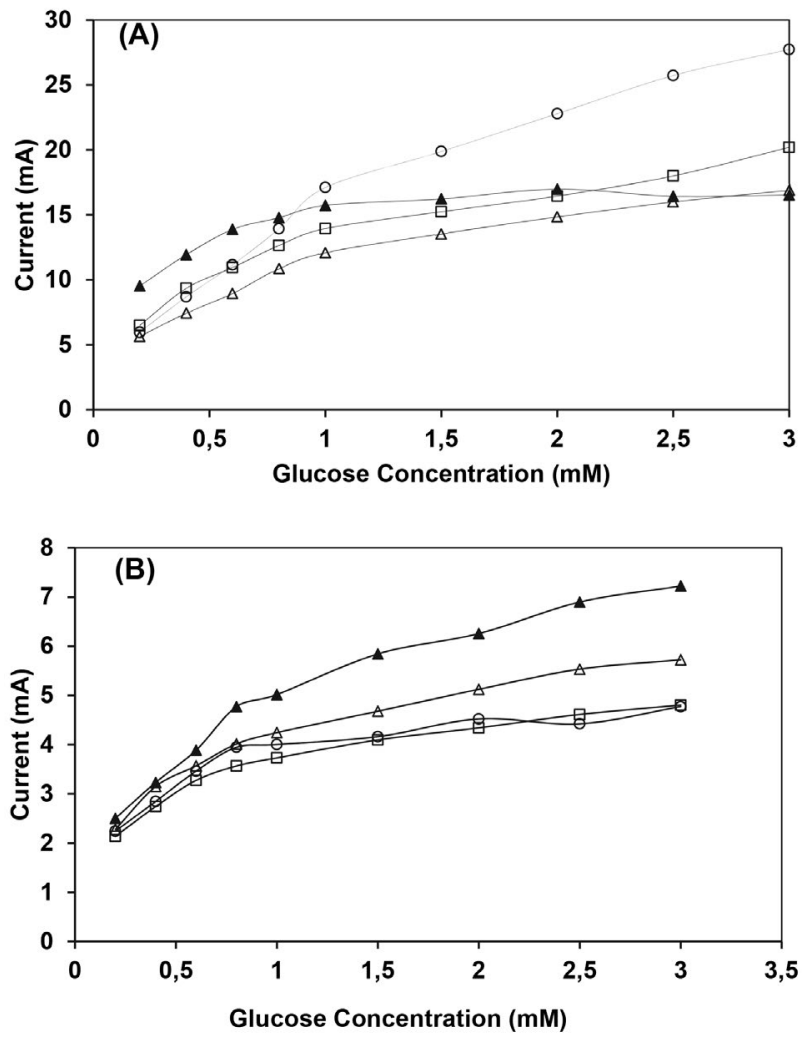

Figure 6. Current response of $\mathrm{PPy}(\mathrm{A})$ and $\mathrm{POA}(\mathrm{B})$ based biosensors modified with ZnONP. $\triangle: \mathrm{ZnONP}$-free; $\boldsymbol{\Delta}: 0.1 ; \square: 0.5$ and $\mathrm{O}: 2$ $\mathrm{mg} \mathrm{ZnONP/ml} \mathrm{Chi.}$

GOD based amperometric biosensor constructed by coating PPy on graphite rod in presence of gold nanoparticle (AuNP), and they reported that, AuNP enhanced the sensor efficieny but, current response decreased by increase in AuNP amount.

\section{3. Electrochemical Characterization of the Enzyme Electrodes}

The glucose sensitivities of electrodes were investigated firstly by cyclic voltammetry technique in glucose free and glucose containing buffer solution. In Fig. 7 (A) and $(\mathrm{B})$ shows the first cyclic voltammograms which were recorded for $\mathrm{Pt} / \mathrm{PPy} / \mathrm{Chi}-\mathrm{GOD}$ and $\mathrm{Pt} / \mathrm{POA} / \mathrm{Chi}-\mathrm{GOD}$ electrodes, respectively, with and without $\mathrm{ZnONP}$. As seen in Fig. 7(A) and 7(B), the current values of $\mathrm{Pt} / \mathrm{PPy} / \mathrm{Chi}-$ GOD and Pt/POA/Chi-GOD electrodes with and without ZnONP remained almost constant in glucose free solution. But, in the glucose solution, current responses started to increase approx. $0.4 \mathrm{~V}$ when compared with current responses of glucose free buffer solution. It was clearly seen that, current values were higher in glucose solution than that of glucose free solution for all enzyme electrodes. This shows us, enzyme electrodes are sensitive to glucose molecule. On the other hand, Pt/PPy/Chi-GOD and Pt/POA/ Chi-GOD electrodes with ZnONP exhibited higher current values than those of $\mathrm{ZnONP}$-free electrodes.
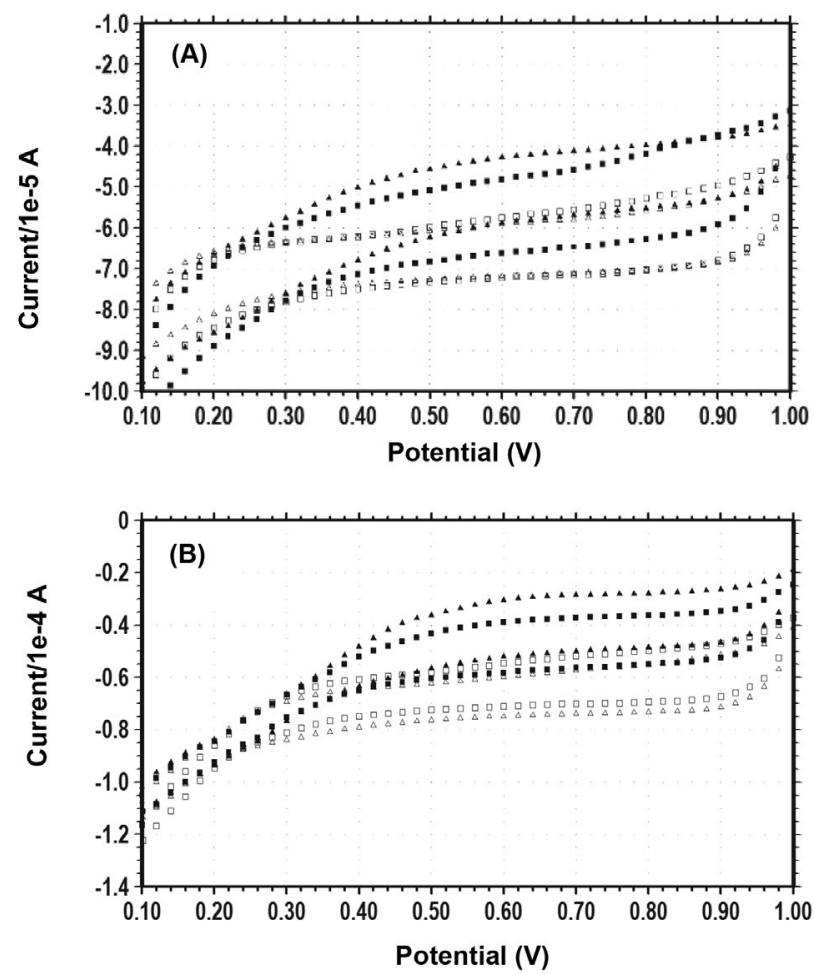

Figure 7. Cyclic voltammograms of nanoparticle free enzyme electrode in the buffer $(\square)$ and in the glucose solution ( $\mathbf{\square})$, cyclic voltammograms of $\mathrm{ZnONP}$ containing enzyme electrodes in the buffer $(\triangle)$ and in the glucose solution $(\mathbf{\Delta})$ for PPy (A) and for POA (B) (5 mM glucose solution).

This proved that $\mathrm{ZnONP}$ contributed to the electron transfer between metal and enzyme active center.

$\mathrm{Pt} / \mathrm{PPy} / \mathrm{Chi}-\mathrm{GOD}$ and $\mathrm{Pt} / \mathrm{POA} / \mathrm{Chi}-\mathrm{GOD}$ electrodes with and without $\mathrm{ZnONP}$ were characterized by EIS technique and Nyquist diagrams are given in the Figure 8(A) and $8(B)$, respectively.

In the Nyquist diagrams, the first and second depressed semicircles at high and low frequencies consisted of charge transfer resistance $\left(\mathrm{R}_{\mathrm{ct}}\right)$ corresponding to the anodic reaction of the substrate at the bottom of the pores and the resistances of the oxide layer $\left(R_{o}\right)+$ polymer film $\left(\mathrm{R}_{\mathrm{f}}\right)$, respectively. The first partial semicircle at the high frequency region is related to $R_{\mathrm{ct}}$ for processes occurring at the bottom of the pores of coatings.

The charge transfer reactions are known to take place at the metal/polymer interfaces. Consequently, the high $R_{\mathrm{ct}}$ values of coated electrodes can be explained by the build-up of protective layers and the effective barrier behavior of films on the surface.

In Fig $8(\mathrm{~A})$, the $\mathrm{R}_{\mathrm{ct}}$ value recorded for $\mathrm{Pt} / \mathrm{PPy} / \mathrm{Chi}$ GOD-ZnONP electrode in glucose free buffer solution was the highest due to forming a barrier layer such as coating, enzyme and nanoparticle on the Pt surface. However, the feature of same electrode was exactly different in the glucose solution with the lowest $R_{c t}$ value. On the other hand, the magnitude of semicircle observed at high fre- 

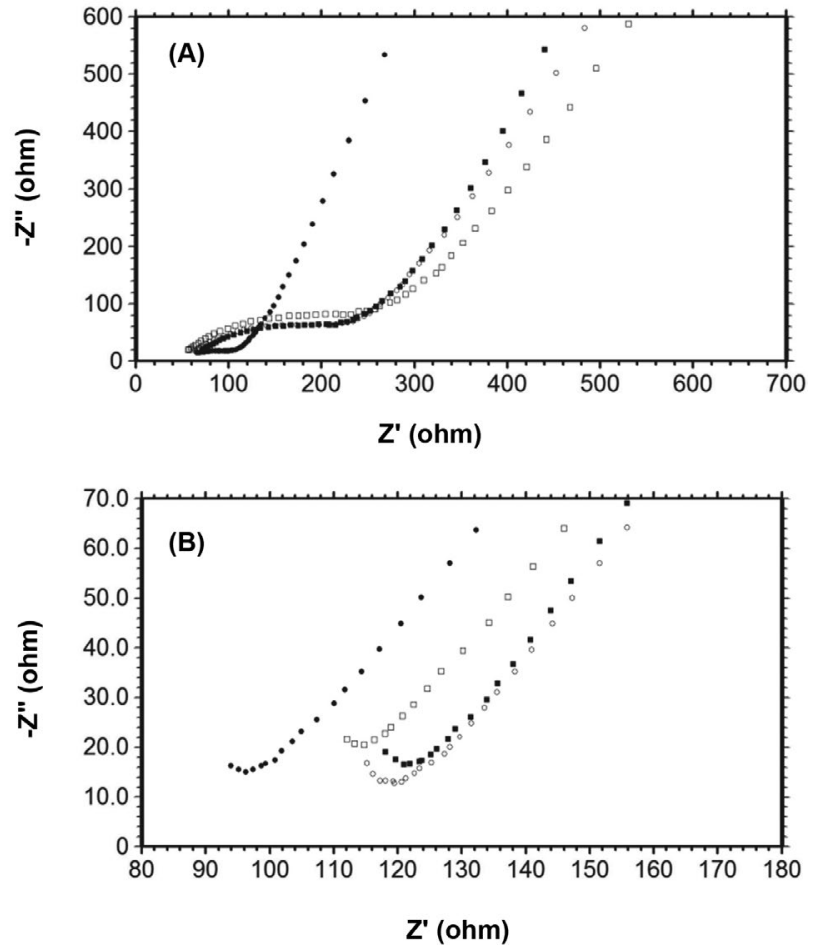

Figure 8. The Nyquist diagrams of Pt/PPY/Chi-GOD/GAL (A) and and Pt/POA/Chi-GOD/GAL (B) electrodes. ZnONP free in the buffer $(\square)$ and in the glucose ( $\square)$, ZnONP containing in the buffer $(\mathrm{O})$ and in the glucose $(\bullet)$ solution.

quency region recorded for Pt/PPy/Chi-GOD electrode in the glucose solution was significantly higher when compared with that the presence of glucose free solution. The lowest $\mathrm{R}_{\mathrm{ct}}$ value recorded for Pt/PPy/Chi-GOD-ZnONP electrode in the glucose solution was related to the increase of the charge transfer rate between the metal and the solution. At the same time, the semicircle observed at high frequency region recorded for Pt/POA/Chi-GOD$\mathrm{ZnONP}$ electrode in the glucose solution is incredibly low when compared with other three semicircles in Fig 8 (B). The low $\mathrm{R}_{\mathrm{ct}}$ values of Pt/PPy/Chi-GOD and Pt/POA/ChiGOD electrodes which were modified with ZnONP showed that $\mathrm{ZnO}$ nanoparticles in glucose solution contributed to the increase in the charge transfer rate at the metal/polymer interfaces. Tang et al. $(2015)^{35}$ prepared GOD based GCE electrode and modified the electrode with PANI and nanometer sized $\mathrm{TiO} 2$. They reported that $\mathrm{n}-\mathrm{TiO}_{2}$ enhanced conductivity and improved the interfacial electron transfer ability.

\section{4. Biochemical Characterization of Enzyme Electrodes}

For biochemical characterization, optimal $\mathrm{pH}$ values, kinetic parameters and operational stabilities were investigated for each electrode. Firstly, current responses were measured in $3 \mathrm{mM}$ glucose solution at different $\mathrm{pH}$ values and results were given in Table 1 . The highest current values were observed at $\mathrm{pH} 6.0$ for GOD-Chi/PPy/Pt, ZnONPGOD-Chi/PPy/Pt and GOD-Chi/POA/Pt whereas at $\mathrm{pH}$ 4.0 for ZnONP-GOD-Chi/POA/Pt. $\mathrm{I}_{\max }$ and $\mathrm{K}_{\mathrm{M}}$ values of each electrode were calculated by Lineweaver-Burk plot using current values depending on glucose concentration of which range between 0.1 and $10 \mathrm{mM}$ and results were given in the Table 1. As seen in Table 1, $\mathrm{I}_{\max }$ values of GOD-Chi/ $\mathrm{PPy} / \mathrm{Pt}, \mathrm{ZnONP}-\mathrm{GOD}-\mathrm{Chi} / \mathrm{PPy} / \mathrm{Pt}$ were considerably higher than those of GOD-Chi/POA/Pt and ZnONP-GODChi/POA/Pt. Besides, $I_{\max }$ values of enzyme electrodes prepared with ZnONP were higher than those of their nanoparticle free counterparts. $\mathrm{K}_{\mathrm{M}}$ values of enzyme electrodes that were modified by $\mathrm{ZnONP}$ were slightly lower.

Metaloxide nanoparticles such as $\mathrm{TiO}_{2}{ }^{35}, \mathrm{CuGeO}_{3}{ }^{44}$, $\mathrm{ZrO}_{2}{ }^{45}, \mathrm{IrO}_{2}{ }^{46}$ were used to enhance the GOD based amperometric biosensor in the literature. Yang et al. (2004) modified the Chi-GOD based amperometric glucose biosensor by $\mathrm{ZrO}_{2}$ nanoparticles and they found $\mathrm{I}_{\max }$ value as $0.29 \mu \mathrm{A}$ whereas $\mathrm{K}_{\mathrm{M}}$ values as $3.14 \mathrm{mM}$. Jhas et.al $(2010)^{45}$ constructed $\mathrm{IrO}_{2}-\mathrm{NP}$ containing GOD electrode and $\mathrm{I}_{\max }$ and $\mathrm{K}_{\mathrm{M}}$ values were calculated as $46 \mathrm{~mA} / \mathrm{m}^{2}$ and $27 \mathrm{mM}$, respectively.

Operational stabilities of the electrodes were also analyzed by 20 successive using in the $5 \mathrm{mM}$ of glucose solution. Studies were repeated five times and results were very similar and SD were between 3.2 and $8.2 \%$. For all 20 cycles, measured currents as the percentage of initial current were calculated and results were given in the Fig.9. As seen, $92.73 \%$ and $93.13 \%$ of initial currents were observed for GOD-Chi/POA/Pt and ZnONP-GOD-Chi/POA/Pt, respectively at the $20^{\text {th }}$ cycle. However, Initial current activities of GOD-Chi/PPy/Pt kept nearly same (100.25\% at the end of $20^{\text {th }}$ cycle) and there was a very slight increase $(102.08 \%)$ compared to the first measured current value in the case of ZnONP-GOD-Chi/PPy/Pt. This could occure because of change in microenvironment of GOD and PPy, that enhance enzyme activity and electron transport rate. It can be easily said that, prepared enzyme electrodes are very stable in terms of reuse.

Table 1. Kinetic parameters and optimal $\mathrm{pH}$ values of GOD electrodes with and without $\mathrm{ZnONP}$

\begin{tabular}{lcccccc}
\hline & & $\mathbf{P P y}$ & & $\mathbf{P O A}$ \\
& $\mathbf{p H}$ & $\mathbf{I}_{\max }(\boldsymbol{\mu} \mathbf{A})$ & $\mathbf{K}_{\mathbf{M}}(\mathbf{m M})$ & $\mathbf{p H}$ & $\mathbf{I}_{\max }(\boldsymbol{\mu} \mathbf{A})$ & $\mathbf{K}_{\mathbf{M}}$ \\
\hline$(\mathbf{m M})$ & & & & & & \\
ZnO-NP-Free & 6.0 & $29.8 \pm 1.2$ & $1.2 \pm 0.1$ & 6.0 & $5.8 \pm 0.2$ & $0.3 \pm 0.0$ \\
ZnO-NP & 6.0 & $40.7 \pm 2.2$ & $1.5 \pm 0.1$ & 4.0 & $8.6 \pm 0.3$ & $0.4 \pm 0.0$ \\
\hline
\end{tabular}




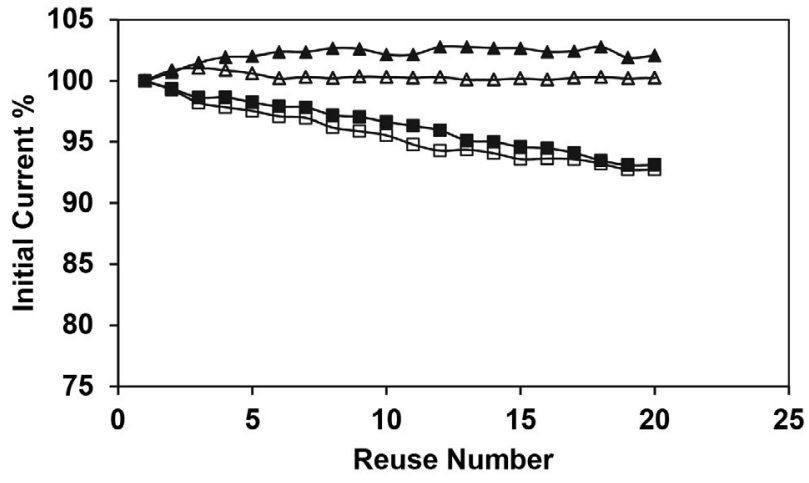

Figure 9. Operational stabilities of enzyme electrodes GOD-Chi/ POA/Pt ( $\square$ ), ZnONP-GOD-Chi/POA/Pt (ם), GOD-Chi/PPy/Pt $(\triangle)$ and ZnONP- GOD-Chi/PPy/Pt $(\boldsymbol{\Delta})$

\section{Conclusion}

PPy and POA coated Pt electrodes were easily and successfully used to construct glucose sensitive enzyme electrode. It was found that electrode construction parameters significantly affected the current values depending on glucose concentration. The current values and stabilities were higher for PPy based electrode than those of POA based electrode. Also, it was revealed that, modification of enzyme electrode by ZnONP contributed to the electron transfer between metal and enzyme active center. This study revealed that biosensor design parameters significantly affect the efficiency of biosensors. Glucose biosensors are one of the most widely used sensor systems in the world. So, the development of more stable and sensitive sensor platforms is extremely important.

\section{Acknowledgements}

This study was funded by Scientific Research Units of The University of Mustafa Kemal in Turkey, Project nos.9080 and 8681.

\section{References}

1. J. G. Manjunatha, Heliyon, 2018, 4, e00986. DOI:10.1016/j.heliyon.2018.e00986

2. N. Hareesha, J. G. G.Manjunatha, C. Raril, G. Tigarl, Adv. Pharm. Bull., 2019, 9, 132-137. DOI:10.15171/apb.2019.016

3. C. Raril, J. G.Manjunatha, Mod. Chem. \&Appl., 2018, 6, 1-8.

4. K. Khun, Z.H. Ibupoto, J. Lu, M.S. AlSalhi, M. Atif, A. Ansari, M. Willander, Sens. Actuators, B 2012, 173, 698-703.

DOI:10.1016/j.snb.2012.07.074

5. A. Salimi, A. Noorbakhsh, Electrochim. Acta, 2011, 56, 60976105. DOI:10.1016/j.electacta.2011.04.073

6. Y. M. Uang, T. C. Chou, Biosens. Bioelectron., 2003, 19, 141147. DOI:10.1016/S0956-5663(03)00168-4

7. M. Guo, H. Fang, R. Wang, Z. Yang, X. Xu, J. Mater. Sci.: Mater. Med., 2011, 22, 1958-1992.
DOI:10.1007/s10856-011-4363-y

8. P. E. Erden, Ş. Pekyardımcı, E. Kılıç, Acta Chim. Slov. 2012, 59, 824-832.

9. J. Kochana, Acta Chim. Slov. 2012, 59, 760-765.

10. M. E. Ghica, C. M. A. Brett, J. Electroanal. Chem., 2009, 629, 35-42. DOI:10.1016/j.jelechem.2009.01.019

11. L. V. Shkotova, N. Y. Piechniakova, O. L. Kukla, S. V. Dzyadevych, Food Chem., 2016, 197, 972-978.

DOI:10.1016/j.foodchem.2015.11.066

12. L. Wang, X. Gao, L. Jin, Q. Wu, Z. Chen, X. Lin, Sens. Actuators $B$, 2013, 176, 9-14. DOI:10.1016/j.snb.2012.08.077

13. Y. Hui, L. Nan, X. Jhing-Zhong, Z. Jun-Jie, Chin. J. Chem., 2005, 23, 275-279. DOI:10.1002/cjoc.200590275

14. B. Haighi, L. Nazari, S. M. Sajjadi, Electroanalysis, 2012, 24, 2165-2175. DOI:10.1002/elan.201200277

15. S. Huang, Y. Ding, Y. Liu, L. Su, R. Filosa Jr, Y. Lei, Electroanalysis, 2011, 23, 1912-1920. DOI:10.1002/elan.201100221

16. R. Pauliukaite, A. M. C. Paquim, A. M. O. Brett, C. M. A. Brett, Electrochim. Acta, 2006, 52, 1-8.

DOI:10.1016/j.electacta.2006.03.081

17. N. Demirkıran, E. Ekinci, Acta Chim. Slov. 2012, 59, 302-306

18. G. Ozyilmaz, A. T. Ozyilmaz, F. Can, Appl. Biochem.Microbiol. 2011, 47, 217-225. DOI:10.1134/S0003683811020153

19. E. H. Yu, K. Sundmacher, Trans IChemE, Part B, Process Saf. Environ. Prot., 2005, 85, 489-493.

20. A. Eftekhari, Synth. Met., 2004, 145, 211-216. DOI:10.1016/j.synthmet.2004.05.016

21. K. Abu-Rabeah, R. S. Marks, Sens. Actuators B, 2009, 136, 516-522. DOI:10.1016/j.snb.2008.09.020

22. F. Ekiz, F. Oğuzkaya, M. Akın, S. Timur, C. Tanyeli, L. Toppare, J. Mater. Chem., 2011, 21, 12337-12343. DOI:10.1039/c1jm12048d

23. R. K. Shervedani, A. Hatefi-Mehrjardi, Sens. Actuators B, 2007, 126, 415-423. DOI:10.1016/j.snb.2007.03.023

24. C. Guadalupe de Jesus, D. Lima, V. Santos, K. Wohnrath, C. A. Pessoa, Sens. Actuators B, 2013, 186, 44-51. DOI:10.1016/j.snb.2013.05.063

25. A. Salimi, A. Noorbakhsh, Electrochim. Acta, 2011, 56, 60976105 . DOI:10.1016/j.electacta.2011.04.073

26. Y. Jiang, Q. Zhang, F. Li, L. Niu, Sens. Actuators B, 2012, 161, 728-733. DOI:10.1016/j.snb.2011.11.023

27. G. Ozyilmaz, A. T. Ozyilmaz, R. H. Akyürekoğlu, Nat. Eng. Sci., 2017, 2, 123-134. DOI:10.28978/nesciences.354825

28. G. Ozyilmaz, A. T. Ozyilmaz, S. Ağçam, Nat. Eng. Sci., 2018, 3, 1-15. DOI:10.28978/nesciences.379311

29. J. Li, R. Yuan, Y. Chai, X. Che, W. Li, Bioprocess Biosys Eng, 2012, 35, 1089-1095. DOI:10.1007/s00449-012-0693-5

30. Zhang Y, Liu Y, Chu Z, Shi L, Jin W, Sens. Actuators B, 2013, 176, 978-984. DOI:10.1016/j.snb.2012.09.080

31. S. Chen, P. Fu, B. Yin, R. Yuan, Y. Chai, Y. Xiang, Bioprocess Biosyst Eng, 2011, 34, 711-719.

DOI:10.1007/s00449-011-0520-4

32. M. Raicopol, A. Prună, C. Damian, L. Pilan, Nanoscale Res. Letters, 2013, 8, 1-8. DOI:10.1186/1556-276X-8-316

33. D. Olea, O. Viratelle, C. Faure, Biosens. Bioelectron., 2008, 23, 788-794. DOI:10.1016/j.bios.2007.08.018 
34. C. Ozdemir, F. Yeni, D. Odaci, S. Timur, Food Chem., 2010, 119, 380-385. DOI:10.1016/j.foodchem.2009.05.087

35. W. Tang, L. Li, X. Zeng, Talanta, 2015, 131, 417-423. DOI:10.1016/j.talanta.2014.08.019

36. P. A. Savale, M. D. Shirsat, Appl. Biochem. Biotechnol. 2009, 159, 299-309. DOI:10.1007/s12010-008-8135-1

37. D. D. Borole, U. R. Kapadi, P. P. Mahulikar, D. G. Hundiwale, J. Mater. Sci., 2007, 42, 4947-4953.

DOI:10.1007/s10853-006-0164-y

38. S. A. Rothwell, S. J. Killoran, R. D. O’Neill, Sensors, 2010, 10, 6439-6462. DOI:10.3390/s100706439

39. M. F. Abasiyanik, M. Senel, J Electroanal Chem, 2010, 639, 21-26. DOI:10.1016/j.jelechem.2009.11.001

40. S. Jung, S. Lim, Appl Surface Sci, 2013, 265, 24-29.

DOI:10.1016/j.apsusc.2012.10.069
41. Y. T. Wang, L. Yu, J. Wang, L. Lou, W. J. Du, W. Q. Zhu, H. Peng, J. Z. Zhu, J Electroanal. Chem., 2011, 661, 8-12. DOI:10.1016/j.jelechem.2011.06.024

42. X. Q. Hou, X. Ren, F. Q. Tang, D. Chen, Z.P. Wang, Chin. J. Anal. Chem., 2006, 34 303-306.

43. N. German, A. Kausaite-Minkstimiene, A. Ramanaviicius, T. Semashko, R. Mikhailova, A. Ramanaviciene, Electrochim. Acta, 2015, 169, 326-333.

DOI:10.1016/j.electacta.2015.04.072

44. Y. P. Dong, L. Huang, X. F. Chu, L. Z. Pei, Russian J Electrochem, 2013, 49, 571-576. DOI:10.1134/S1023193513060037

45. Y. Yang, H. Yang, M. Yang, Y. Liu, G. Shen, R. Yu, Anal. Chim. Acta, 2004, 525, 213-220. DOI:10.1016/j.aca.2004.07.071

46. A. S. Jhas, H. Elzanowska, B. Sebastian, V. Birss, Electrochim. Acta, 2010, 55, 7683-7689.

DOI:10.1016/j.electacta.2010.03.093

\section{Povzetek}

GOD smo imobilizirali na Pt elektrodo, prevlečeno s poliprolom (PPy) ali poly(o-anizidinom) (POA), in tako skonstruirali biosensor, občutljiv na glukozo. Ker lastnosti filma in encimska aktivnost vplivajo na tokovni odziv elektrode, smo natančno optimizirali sintezne pogoje za PPy in POA in tudi parametre za imobilizacijo encima. Optimalna monomerna koncentracija je bila $25 \mathrm{mM}$ za PPy in $50 \mathrm{mM}$ za POA, medtem ko je bila hitrost skeniranja za oba polimerna filma 50 $\mathrm{mV} / \mathrm{s}$. V primeru imobilizacijskega postopka so bile optimalne koncentracije kitozana (Chi), glukoza oksidaze (GOD) in glutaraldehida (GAL) enake $0,5 \%, 2 \mathrm{mg} / \mathrm{ml}$ in $0,05 \%$ za PPY in 0,5 \%, $4 \mathrm{mg} / \mathrm{ml}$ in 0,075 \% za POA. Hkrati smo z encimom GOD imobilizirali tudi nanodelce cinkovega oksida (ZnONP) in pokazalo se je, da modifikacija $\mathrm{z}$ ZnONP poveča učinkovitost obeh elektrod s stališča tokovnega odziva in stabilnosti. Nyquistovi diagrami so pokazali, da sta bili obe encimski elektrodi občutljivi na molekule glukoze in da je modifikacija z ZnONP izboljšala učinkovitost senzorja.

Except when otherwise noted, articles in this journal are published under the terms and conditions of the Creative Commons Attribution 4.0 International License 